\title{
Tadsjikistan: Flerkoneri og masseudvandring
}

Marcus Rubin

Ti år efter sin blodige borgerkrig er Afghanistans nordlige nabo Tadsjikistan stabil, men ludfattig og autokratisk ligesom sine centralasiatiske naboer. Og fremtiden tegner ikke meget bedre. Islam er i hastig fremmarch, og mange frygter udviklingen går i retning af et mere repressivt regime

Fråden står næsten om munden på Shafoart Fathukeva, når talen falder på mændene i hendes land. Og det er ikke af begejstring. "Svin. De er alle sammen nogle svin," siger hun og ser rasende på de mænd, som kommer forbi hendes skostand på tøjmarkedet lidt uden for Tadsjikistans overraskende charmerende hovedstad Dushanbe. Årsagen til Shafoart og de fleste andre kvinders vrede i Tadsjikistans er enkel: Det traditionelle muslimske flerkoneri, som var bandlyst og ekstremt sjældent under Sovjetunionen, er efter USSR's kollaps atter blevet en helt normal og socialt accepteret ting blandt tadsjikiske mænd.

Ganske vist er polygami formelt set stadig forbudt, og Tadsjikistans præsident, Emanoli Rakhmon, har udtalt sig kritisk om det. Men samfundet ser igennem fingre med det, og uanset hvem man taler med - og hvad køn de har - er alle enige om, at det er blevet uhyre udbredt. "95 procent af mændene på min mands fabrik har 2-3 koner" siger Shafoarts kollega Mohira, der uopfordret blander sig i samtalen.

"Manden spørger ikke sin kone, om han må gifte sig med en anden, han gør det bare. Og når hans kone nr. et så før eller siden hører det fra naboerne og konfronterer ham med det, siger han bare, at hvis hun ikke kan lide det, kan hun jo blive skilt. Vel vidende at det har hun ikke råd til, og så bliver hun nødt til at finde sig i det," forklarer hun, og bliver 
straks suppleret af Shafoart: "Det er helt forfærdeligt for dem. De er ydmyget og tit reduceret til en slags husholderske, mens manden morer sig med den nye kone og bruger pengene på hende. Så er det klart bedre at være kone nummer to eller tre. De ved hvad de går ind til, og de får en mand som giver dem en lejlighed og forkæler dem. Og hvis de får børn, kan det sagtens være, at han ender med at være mere hos dem end hos sin første kone, fordi han synes hun er blevet gammel og grim”.

\section{De muslimske rødder}

Flerkoneriets genkomst er et af de mest synlige symboler på, hvor meget det er gået tilbage for det lille bjergrige land i Centralasiens hjerte, siden Sovjetunionen brød sammen i 1991, og Tadsjikistan meget mod sin vilje blev selvstændigt.

Modsat i de baltiske lande og i selve Rusland var der ingen selvstændighedsbevægelse i Tadsjikistan, og som en midaldrende mand udtrykker det "faldt selvstændigheden ned fra himlen. Vi havde intet gjort for den og var overhovedet ikke forberedt".

Som sine centralasiatiske naboer genfandt Tadsjikistans befolkning derfor hurtigt deres muslimske rødder, som var blevet undertrykt i Sovjettiden, hvilket flerkoneriet er et tydeligt tegn på. For ganske vist har præsident Rakhmon indtil videre med succes isoleret islamisterne, der ellers ifølge fredsaftalen fra 1997 fik en del af magten, og slået hårdt ned på blandt andet Hizb ut-Tahir. Men socialt spiller islam en hastigt stigende rolle, og taler man med mændene i landet, bliver flerkoneriet typisk forklaret med henvisning til islam.

Og polygami er kun det mest markante eksempel på den islamiske vækkelse. Unge tadsjikere af begge køn erklærer åbent, at islam er deres moralske kompas, moskeerne skyder op som de lokale champignoner, og mange kvinder er begyndt at gå med tørklæder - så mange at der blandt de udenlandske ngo'er går rygter om, at udenlandske islamister betaler kvinder for at gå med hijab.

Men flerkoneriet handler om mere end islam. Dets genkomst er også et symptom på den massive $\varnothing$ konomiske krise, som har præget Tadsjikistans første 15 år som selvstændig nation og betydet at op i mod halvanden millioner ud af Tadsjikistans samlede befolkning på omkring syv millioner i dag arbejder i udlandet.

Eftersom langt de fleste migranter er mænd, er næsten hver tredje mand flyttet fra landet. Og det er vel og mærke når man inkluderer alle mænd, fra smådrenge til oldinge. I de erhvervsaktive aldersgruppe er tallet formentlig oppe på omkring halvtreds procent, hvilket betyder, at kønsbalancen er blevet markant forrykket, og at der er en udbredt mangel på mænd - med den forudsigeli- 
ge konsekvens at de tilbageværende udnytter situationen og de desperate kvinder.

\section{Udvikling til det værre}

De fleste af Tadsjikistans problemer var åbenbare fra starten og er for hovedpartens vedkommende kun blevet værre siden selvstændigheden i 1991. Få sovjetrepublikker var dårligere forberedt på uafhængighed end Tadsjikistan, da USSR gik i opløsning. Stalins arbitrært fastsatte grænser placerede de store tadsjikiske byer Bukhara og Samarkand i Usbekistan, og ud over en stor aluminiumsindustri og nogle bomuldsmarker blev Tadsjikistan efterladt med deprimerende få økonomiske aktiver.

Bedre bliver det ikke af at langt det meste af landet - over 90 procent - består af uvejsomme bjerge, hvilket både begrænser mulighederne for opdyrkning og transporten internt i landet. Hele den østlige del af landet er utilgængeligt fra oktober til maj, og vejen mellem Dushanbe og Khojand - de to største byer i Tadsjikistan - løber gennem bjergpas, hvilket betyder den er lukket på grund af sne omkring halvdelen af året.

Som prikken over i'et er Tadsjikistan ikke bare landlocked, men dobbelt landlocked - man skal gennem mindst to lande for at komme til havet.

Og var udgangspunktet dårligt, blev det hurtigt værre. Umiddelbart efter selvstændigheden udbrød en blodig borgerkrig i landet, som varede seks år og kostede op i mod 100.000 mennesker livet. Krigen ødelagde store dele af den infrastruktur, som Sovjetunionen havde opbygget, og efterlod Tadsjikistan endnu mere forarmet og traumatiserede befolkningen, der stadig mere end noget andet er fokuseret på sikkerhed og stabilitet.

På den front har præsident Rakhmon og hans regering leveret varen. Tadsjikistan er i dag helt sikkert, og hverken udenlandske eksperter eller folk på gaden forventer at krigen - eller andre konflikter fx med yderligtgående muslimer - er i fare for at blusse op i de kommende år.

Tidligere problemer med ekstremistiske grupper fra Usbekistan og Afghanistan, der i 1990'erne brugte Tadsjikistan som træningsområde og sikkert tilflugtssted, er med succes og international bistand blevet bekæmpet, og selv i den tadsjikiske del af Fergana-dalen ånder alt i dag fred.

Men det er også stort set den eneste bedrift, regeringen kan rose sig af. På alle andre områder står det skralt til. Infrastrukturen er endnu ikke genopbygget efter borgerkrigen. På trods af at Tadsjikistan har uhyre vandressourcer, er vandet sundhedsfarligt i de større byer, fordi ledningssystemet er blevet ødelagt under krigen, og vand fra floderne nu udledes direkte i systemet, hvilket har givet indtil flere koleraepidemier i hovedstaden. Endnu 


\section{MARCUS RUBIN}

værre står det til med energiforsyningen, hvor der selv i de større byer ofte ikke er elektricitet.

I Khojand, den største og rigeste by i den nordlige del af landet $o g$ nationens økonomiske centrum, var der eksempelvis denne vinter - der var usædvanlig hård - kun strøm omkring to timer om dagen og ingen gas, hvilket efterlod beboerne reduceret til at varme sig og lave mad ved tænde bål i gaderne og gårdene. Som en ung mand fra Khojand, der tidligere har arbejdet for OECE og FN, udbrød, da han viste rundt på det regionale museum og så stenalderudstillingen med en familie forsamlet omkring bålet, "er der ikke sket meget i landet. Det er stadig sådan vi lever.”

Ingen kender de officielle dødstal, men læger i Sugdh regionen, som Khojand er en del af, anslår, at over 1.000 mennesker er døde af kulde i løbet af vinteren. I hovedstaden Dushanbe er elforsyningen mere stabil, men her er vandforsyningen plaget af kolera-udbrud og gasforsyningen afbrudt det meste af vinteren, så befolkningen også her ofte er tvunget til at varme sig ved bål - en praksis, der i løbet af vinteren har reduceret hovedstadens bænke til afpillede stålstativer.

\section{Manglende økonomisk vækst}

$\varnothing$ konomien er aldrig for alvor kommet sig efter Sovjetunionens kollaps, og det i sig selv ugunstige udgangs- punkt er siden blevet yderligere forværret af den ustabile situation i Afghanistan og det ekstremt anstrengte forhold til Usbekistan, der under præsident Islam Karimov forsøger at gøre sig selv til den regionale supermagt og tvinge de mindre lande til at acceptere dets lederskab og gør det vanskeligt for Tadsjikistan at eksportere sine varer.

De politiske problemer med Usbekistan har således indtil videre umuliggjort realiseringen af et energisamarbejde med Kirgisistan.

Aftalen ville udjævne el-produktionen og gøre det lettere for Tadsjikistan at forsyne befolkningen med el om vinteren - hvor mængden af hydroenergi er meget begrænset men den har ikke kunnet implementeres, fordi elkablerne som et levn fra sovjettiden går gennem Usbekistan.

Den økonomiske vækst er også hæmmet af en udbredt korruption Tadsjikistan er nummer 142 på Transparancy Internationals liste, side om side med Sierra Leone og Turkmenistan - som gennemsyrer alle dele af samfundet. Fra toppen hvor præsident Rakhmons ni børn alle har fået lukrative kontrakter og koncessioner - en datter har en supermarkedskæde, en anden et mobiltelefonselskab, en tredje en kæde af juvelerbutikker - til det øvrige samfund.

Eksamensbeviser sælges åbent på universiteterne, det er vanskeligt og ofte umuligt at få behandling på de 
statslige hospitaler, medmindre der betales under bordet, og politiet er generelt anset som gennemkorrumperet. Usikkerhed omkring ejerforholdene af de fleste ejendomme folk kan blive tvangsflyttet uden erstatning for herlighedsværdien, fordi staten ejer stort set al jord - øger på en og samme gang mulighederne for magtmisbrug og mindsker incitamenterne $i$ at vedligeholde bygninger og forretninger.

For at gøre ondt værre er Tadsjikistan blevet en af hovedtransportvejene for den afghanske narkoproduktion, hvilket har skabt en meget betydelig sort økonomi - nogle anslår at den udgør helt op imod halvdelen af den officielle økonomi.

Grænsen til Afghanistan blev tidligere bevogtet af omkring 30.000 russiske soldater, men efter en debat mellem præsident Rakhmon og præsident Putin er de blevet trukket ud, og Tadsjikistan står i dag selv for bevogtningen af den lange og uhyre porøse grænse. En opgave hæren langtfra kan magte, og det anslås, at omkring 80 procent af den del af den afghanske narkoproduktion, som smugles gennem Centralasien, kommer via Tadsjikistan.

Ud over narko er der også en betydelig traffiking af tadsjikiske kvinder, primært til prostitution i Dubai.

\section{Migration og brain-drain}

Resultatet af denne næsten endeløse liste af problemer er den massive ar- bejdsmigration. Ganske vist sender migranterne betydelige summer tilbage til Tadsjikistan og bidrager derved meget til økonomien, men samlet set gør udvandringen landet både mere sårbart og potentielt ustabilt. Som anført har det været en afgørende faktor i det udbredte polygami - som trods en tilsvarende muslimsk revival ikke kendes i de øvrige centralasiatiske lande - men også herudover er konsekvenserne uhyre markante.

Udvandringen medfører et massivt brain-drain - stort set alle universitetsstuderende regner med at tage til udlandet og arbejde i nogle år, og mange tvivler på, de kommer tilbage - og gør det uhyre vanskeligt for alvor at løsrive sig fra Ruslands traditionelle overherredømme.

I det hele taget er forholdet til Rusland uhyre komplekst og med stort potentiale for konflikt. På den ene side er Tadsjikistan dybt afhængig af Rusland og de muligheder, dets hastigt voksende økonomi giver, på den anden side øger udvandringen til Rusland afhængigheden af den tidligere kolonimagt.

Som en kvinde, hvis mand arbejdede i den russiske olieindustri udtrykte det, "så hader jeg nok inderst inde russerne. Jeg synes, de har ødelagt så meget for os, og de diskriminerer stadigvæk mod os. Men på den anden side ved jeg ikke, hvordan vi skulle klare os uden dem."

Udfordringer er der med andre ord rigeligt af for Tadsjikistan, og 
ikke mindst i det lys har præsident Rakhmons seneste politiske initiativer vakt en del undren og megen bekymring. I foråret skiftede præsidenten efternavn fra Rakhmonov til Rakhmon og opfordrede i den tadsjikiske patriotismes navn sine medborgere til på samme måde at droppe den russiske afslutning på navnet.

Navneskiftet blev kort efter fulgt op med et dekret om at studenter ikke længere må køre til universitetet på grund af mangel på parkeringspladser, og for at gøre forvirringen fuldkommen fulgte kort efter et forbud mod at holde for store studenterfester og bryllupper. Ved flere lejligheder de senere måneder har politiet således stormet private fester - der traditionelt er meget store og trods værternes protester konfiskeret mad og drikke.

"Det er begyndelsen på enden," kommenterer en universitetsstuderende i Dushanbe præsidentens seneste initiativer. "Er der en lektie vi har lært af de sidste 15 år i Centralasien er det, at når først en regering begynder at blande sig i privatlivet på den måde, ender det galt. Så er der ikke noget naturligt sted at stoppe, og pludselig er det hele blevet forvandlet til en politistat," siger han og forklarer, at han af samme grund er begyndt at søge arbejde i udlandet. "Jeg har ikke lyst til at bo i noget, der minder om Turkmenistan eller Usbekistan. Og det er der vi er på vej hen.”
Helt så dystert ser hans ven, der har været lokalansat i det europæiske udviklingsbank EBRD ikke på dette, men også han er dog bekymret.

"Selve det at præsidenten beskæftiger sig med den slags, er ikke noget godt tegn. Tadsjikistan har så utroligt mange problemer, og det er så meget som skal gøres. Og at han så bruger tiden på dette..." Han lader sætningen stå lidt i luften før han fortsætter. "En ting er i al fald sikker. Hvis der havde været nogen meningsfyldt opposition, havde det været anderledes. Nu kan præsidenten gøre som det passer ham.”

\section{Beskedne håb for fremtiden}

Uanset hvad man mener om præsident Rakhmon, er realiteten, at Tadsjikistan efter ti års fred ikke er kommet nærmere et egentligt demokrati - snarere tværtimod. Ved præsidentvalget sidste år blev præsidenten genvalgt med massivt flertal - omkring 80 procent af stemmerne - efter en proces som de internationale observatører fra OESC i deres efterfølgende rapport erklærede, havde været uhyre mangelfuld.

Efter deres vurdering havde valget ikke været udtryk for nogen meningsfyldt politisk proces på grund af manglende politisk debat, og fordi de øvrige kandidater var stort set totalt ukendte i befolkningen. Et indtryk, der bliver bekræftet når man taler med tadsjiker, der for 
manges vedkommende decideret kom til at grine, når de skulle forklare om de øvrige kandidater. Der er en udbredt opfattelse af, at de øvrige kandidater reelt var udpeget af Rakhmon, og ikke havde nogen meningsfyldt politisk platform.

Trods dette er der dog stadig en betydelig accept i befolkningen af regimet som garant for stabilitet $o g$ fred, og håbene for fremtiden er belært af erfaringen - uhyre besked- ne. Som en universitetsuddannet kvinde i slutningen af 40'erne fra hovedstaden udtrykker det:

"Om ti år håber jeg, at vi har rent vand og elektricitet hele tiden. Ellers vil alt være som det er i dag". Hun tænker lidt og tilføjer. "Måske er det så en af Rakhmons sønner, som er præsident”.

Marcus Rubin er journalist på Politiken 